УДК 615.1:615.322:338.33

DOI https://doi.org/10.11603/2312-0967.2021.3.12395

\title{
PELARGONIUM SIDOIDES, HEDERA HIBERNICA TA ORIGANUM VULGARE B СКЛАДІ ФАРМАЦЕВТИЧНИХ ПРЕПАРАТІВ, ПРЕДСТАВЛЕНИХ НА РИНКАХ УКРАЇНИ ТА ПОЛЬЩІ
}

\author{
О. Р. Брида, Н. Є. Стадницька \\ Національний університет «Львівська політехніка», Львів \\ brydaoleksandr@gmail.com, nataliia.y.stadnytska@lpnu.ua
}

ІНФОРМАЦІЯ

Надійшла до редакції / Received: 22.03.2021

Після доопрацювання / Revised: 07.09.2021

Прийнято до друку / Accepted: 08.09.2021

\section{Ключові слова:}

корені пеларгонії очиткової radix Pelargonium Sidoides;

трава материнки звичайної herba Origani vulgare;

листя плюща звичайного folia Hedera hibernica;

препарати на основі рослинної сировини;

фрармацевтичний ринок України; фрармацевтичний ринок Польщі.

\section{АНОТАЦІЯ}

Мета роботи. Провести аналіз асортименту лікарських препаратів фрармацевтичних ринків України та Польщі, які містять у своєму складі субстанції коренів пеларгонії очиткової (Pelargonium Sidoides), трави материнки звичайної (Origanum vulgare) та листя плюща звичайного (Hedera Hibernica). На підставі одержаних результатів визначити доцільність розробки нового багатокомпонентного препарату з їхнім вмістом.

Матеріали і методи. Аналіз фармацевтичних ринків проводили згідно 3 даними Державного реєстру лікарських засобів України та Польщі (станом на липень 2021 р.). Роботу виконано з використанням логічного, статистичного та грасрічного методів.

Результати й обговорення. Більшість проаналізованих засобів срармацевтичних ринків України та Польщі із вмістом пеларгонії очиткової, материнки звичайної, плюща звичайного представлена у фрормі сиропів. В основному, це однокомпонентні лікарські засоби (73,33 \% в Україні та 91,7 \% в Польщі). В обох країнах найбільший відсоток досліджуваних препаратів вироблені на вітчизняних фрармацевтичних підприємствах, на другому місці препарати, імпортовані з Німеччини. Найчастіше лікарські препарати із вмістом Origanum vulgare, Hedera Hibernica, Pelargonium Sidoides - це засоби, що застосовуються у разі кашлю та застудних захворювань $(78,21 \%)$.

Висновки. Розробка нового багатокомпонентного лікарського засобу із вмістом трави материнки, листя плюща і коренів пеларгонії є перспективною, оскільки аналогів такого препарату на проаналізованих фрармацевтичних ринках немає.
Вступ. За даними Центру громадського здоров'я МО3 України, на захворювання верхніх дихальних шляхів хворіють від 35 до 150 тис. громадян на тиждень [1]. За статистикою пацієнти найчастіше довіряють і віддають перевагу лікам, в основу яких входить лікарська рослинна сировина [2]. Фітопрепарати мають ряд переваг, зокрема, менш токсичні, що особливо важливо при лікуванні хронічних захворювань, їх можна застосовувати тривалий час. Важли- вим фрактором $є$ й те, що більшість 3 них дозволена до безрецептурного продажу, і вони не можуть викликати антибіотикорезистентність.

Препарати на основі пеларгонії очиткової (Pelargonium sidoides) підвищують активність імунного захисту в пацієнтів із ГРВІ та рекурентними інфекціями верхніх дихальних шляхів. При їх застосуванні спостерігається зростання кількості NK-клітин, які можуть безпосередньо розпізнавати вірусні пато-

ISSN 2312-0967. Pharmaceutical review. 2021. № 3 
Фармацевтичний менеджмент, маркетинг та логістика Pharmaceutical management, marketing and logistics

гени [3]. Зокрема, серед речовин, що містяться в екстракті пеларгонії очиткової, можна виділити проантоціанідини, які є хорошими кандидатами для тривалого та нешкідливого лікування інорекційних захворювань [4, 5].

Материнка звичайна (Origanum vulgare) містить до 1,2 \% ефрірної олії, до складу якої входять: тимол, цимол, карвакрол, які мають відхаркувальну, протизапальну, знеболювальну дію, завдяки чому входять до складу зборів грудного і потогінного, які приймають при захворюваннях верхніх дихальних шляхів, застуді. Материнка також проявляє антиоксидантні властивості, що в поєднанні з деякими ліками підвищує антибактеріальну дію останніх. В літературі описано поєднання трав материнки та чебрецю, з метою одержання багатокомпонентного лікарського засобу із високим вмістом тимолу і карвакролу, що потенційно матиме застосування для лікування захворювань верхніх дихальних шляхів [6, 7].

Листя плюща (Hedera hibernica) здавна використовують при лікуванні захворювань верхніх дихальних шляхів. Висушений екстракт листя плюща проявляв високу ефективнисть і добру переносимість у пацієнтами із бронхітом [8]. Дослідження антимікробної активності екстрактів листя плюща показали, що вони затримують ріст колоній семи штамів мікроорганізмів, зокрема: Staphylococcus aureus, Staphylococcus epidermidis, Listeria monocytogenes, Campylobacter jejuni та Candida Albicans [9].

Сучасні дані свідчать, що препарати на основі екстрактів із листя плюща можуть покращити частоту та інтенсивність кашлю, пов'язаного з вірусною респіраторною інфекцією. Ряд досліджень демонструє, що гедерасапонін В, що міститься в 30 \% етанольному екстракті листя плюща, виявляє значну противірусну активність щодо субгенотипів EV3 C3 та C4а завдяки зменшенню утворення видимого СРЕ. Гедерасапонін В також пригнічує вірусну експресію білка VP2, що свідчить про пригнічення синтезу вірусного капсидного білка [10].

Мета роботи. Провести аналіз асортименту лікарських препаратів фрармацевтичних ринків України та Польщі, які містять у своєму складі субстанції коренів пеларгонії очиткової, трави материнки звичайної та листя плюща звичайного. На підставі одержаних результатів визначити доцільність розробки нового багатокомпонентного препарату з їхнім вмістом.

Матеріали і методи. Дослідження асортименту препаратів проводили станом на липень 2021 р. 3 огляду на дані Державного реєстру лікарських засобів України [11] та Rejestr Produktów Leczniczych (Peєстру препаратів лікувальних Польщі) [12] та кваліфрікаційну систему ATC (Anatomical Therapeutic Chemical classification system) [13]. Використано статичний, графрічний і логічний методи. Проведено маркетингові дослідження та проаналізовано асортиментну структуру препаратів трави материнки, листя плюща та коренів пеларгонії очиткової, які згідно зі ст. 9 Закону України «Про лікарські засоби», можна застосовувати в Україні після їхньої державної реєстрації [14].

Результати й обговорення. Станом на липень 2021 року на фрармацевтичному ринку України зареєстровано 18 препаратів материнки трави Origani herba, 29 препаратів листя плюща звичайного Hedera hibernica та 14 препаратів на основі пеларгонії очиткової Pelargonium Sidoides [7]. На ринку Польщі препаратів материнки на даний момент не зареєстровано або вже закінчився термін реєстраційних посвідчень, присутні 23 препарати листя плюща і 3 препарати пеларгонії очиткової.

Стосовно фрармацевтичного ринку України, найбільше лікарських засобів на основі аналізованих рослин представлено у вигляді сиропів (16 одиниць найменувань препаратів) або рідких лікарських фрорм, таких як настойки (розчини) або краплі (12 одиниць найменувань препаратів), на другому місці - таблетки (10 одиниць найменувань препаратів). У свою чергу, по 7 одиниць мають екстракти та лікарська рослинна сировина ЛРС у вигляді грудних зборів або чаї для приготувань. Найменша частка належить мазям - 1 одиниця.

Зареєстровані лікарські форми із даними рослинами в Україні продемонстровані на рисунку 1, у Польщі - на рисунку 2.

На фрармацевтичному ринку Польщі зареєстровано лікарські засоби із вмістом рослин, що аналізуються лише у 4 фрормах (див. рис. 2), а саме у краплях або розчинах (1 препарат на основі плюща звичайного), екстрактів (по 1 препарату плюща та пеларгонії), таблеток та пастилок (4 препарати із вмістом плюща та 1 препарат із вмістом пеларгонії), сиропів (17 препаратів із вмістом плюща та 1 препарат із вмістом пеларгонії).

Проведено аналіз асортименту препаратів із вмістом трави материнки звичайної на належність відповідної фрармакологічної групи згідно 3 АТCкласифрікацією (табл. 1).

Згідно з даними, представленими на рисунку 3 , найбільша частка асортименту препаратів материнки звичайної припадає на препарати групи N05 психолептичні засоби (38,46 \%, 5 од.). Представлені препарати групи R05 засоби, що застосовуються у разі кашлю та застудних захворювань, складають 30,77 \% асортименту. Відповідно частка групи препаратів G04 засоби, що застосовуються в урології, складає 23,08 \% (3 од.). У свою чергу, G02 інші гінекологічні засоби представлена лише одним лікарським засобом, що становить 7,69 \% асортименту.

3 огляду на вищезазначене, препарати плюща звичайного виявлені на обох досліджуваних фрармацевтичних ринках. Проведено їхній аналіз стосовно приналежності до відповідної фрармакологічної групи

ISSN 2312-0967. Фармацевтичний часопис. 2021. № 3 


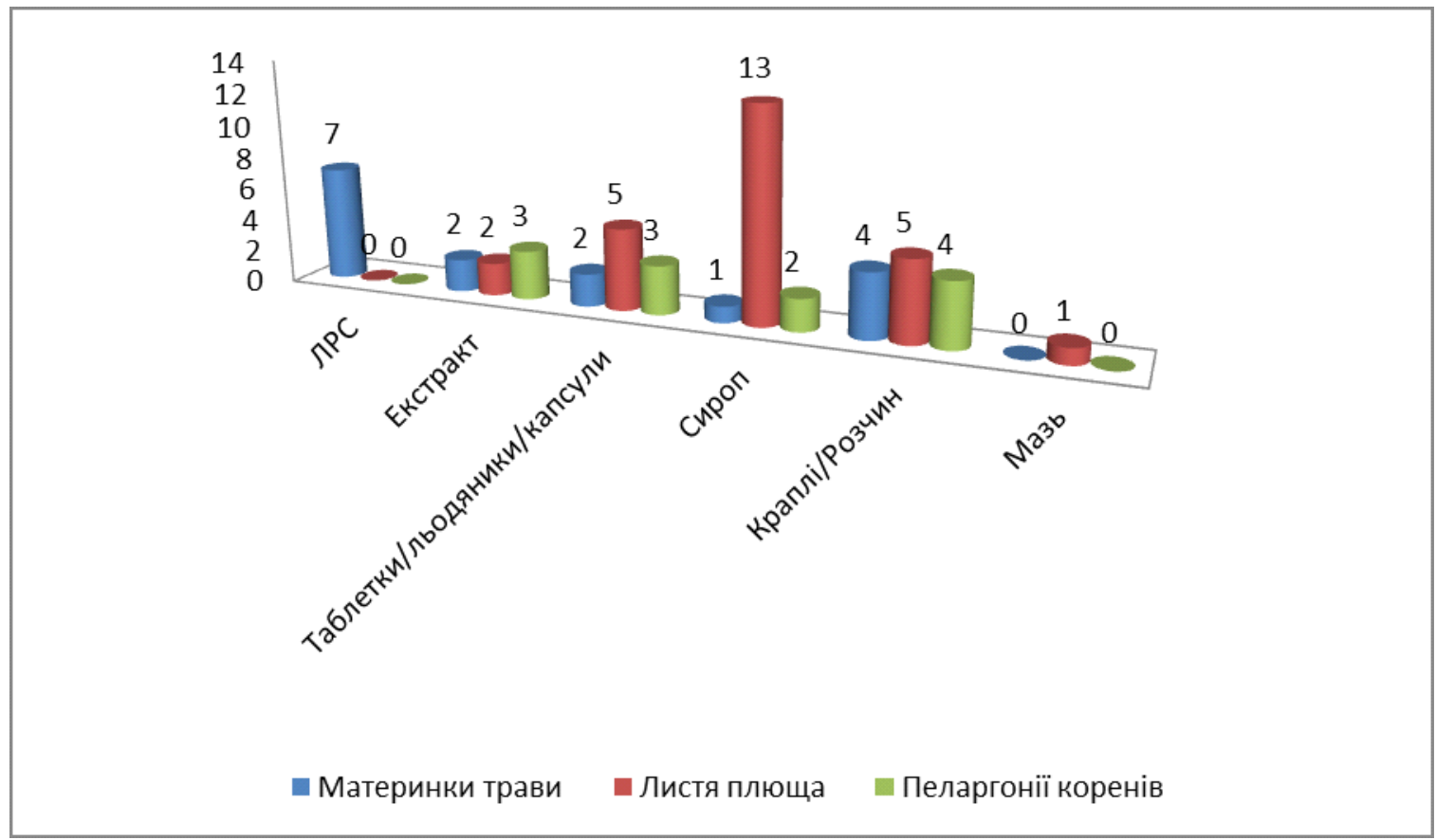

Рис. 1. Кількість зареєстрованих лікарських форм із вмістом материнки трави, листя плюща та коренів пеларгонії в Україні.

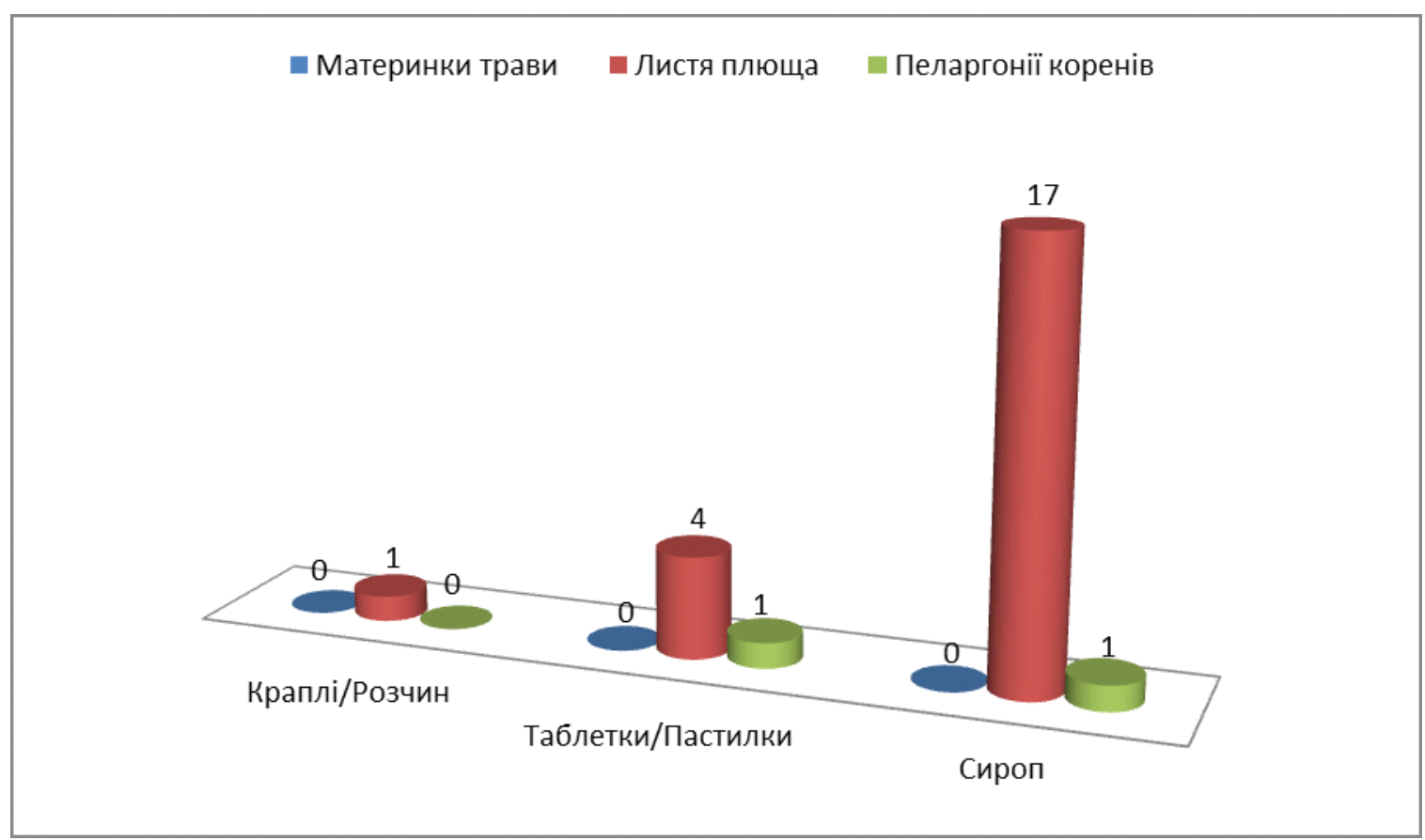

Рис. 2. Кількість зареєстрованих лікарських фрорм із вмістом материнки трави, листя плюща та коренів пеларгонії в Польщі.

згідно з АТС-класифрікацією (табл. 2) і встановлено, що майже всі належать до засобів, що застосовуються у разі кашлю та застудних захворювань.

Найбільша частка асортименту препаратів плюща звичайного на ринку України припадає на препарати групи R05 засоби, що застосовуються у разі кашлю та застудних захворювань (97,83 \%, 45 од.). У свою чергу, групи препаратів V03 інші засоби, складає 2,17 \% (1 од.). На фрармацевтичному ринку Польщі усі лікарські засоби на основі листя плюща віднесені до групи препаратів, які застосовуються у разі кашлю та застудних захворювань.

ISSN 2312-0967. Pharmaceutical review. 2021. № 3 
Фармацевтичний менеджмент, маркетинг та логістика Pharmaceutical management, marketing and logistics

\section{Таблиця 1}

Розподіл наявних на фрармацевтичному ринку України препаратів материнки звичайної залежно від їхньої класифікації АТС

\begin{tabular}{|c|c|c|c|}
\hline $\begin{array}{l}\text { Назва групи згідно із } \\
\text { АТС-класифрікацією, } \\
\text { фрармакологічна дія }\end{array}$ & Рослинні компоненти & $\begin{array}{c}\text { Препарати, лікарська } \\
\text { фрорма }\end{array}$ & Виробник \\
\hline 1 & 2 & 3 & 4 \\
\hline \multirow{4}{*}{$\begin{array}{l}\text { R05 засоби, що } \\
\text { застосовуються у разі } \\
\text { кашлю та застудних } \\
\text { захворювань, } \\
\text { Відхаркувальна }\end{array}$} & Материнки трава & $\begin{array}{l}\text { Материнки трава, фрільтр- } \\
\text { пакети }\end{array}$ & $\begin{array}{l}\text { ПрАТ Фармацевтична } \\
\text { фрабрика «Віола», Україна }\end{array}$ \\
\hline & Материнки трава & $\begin{array}{l}\text { Материнки трава, } \\
\text { трава по } 50 \text { г або } 75 \text { г у } \\
\text { пачках } 3 \text { внутрішнім пакетом; } \\
\text { по 1,5 г у фрільтр-пакеті }\end{array}$ & ПрАТ «Ліктрави», Україна \\
\hline & $\begin{array}{l}\text { Алтеї корені; } \\
\text { Мати-й-мачухи листя; } \\
\text { Материнки трава }\end{array}$ & $\begin{array}{l}\text { Грудний збір № } 1 \\
\text { збір, срільтр-пакети }\end{array}$ & $\begin{array}{l}\text { ПрАТ Фармацевтична } \\
\text { фрабрика «Віола», } \\
\text { Україна }\end{array}$ \\
\hline & $\begin{array}{l}\text { Алтеї корені } \\
\text { Мати-й-мачухи листя } \\
\text { Материнки трава }\end{array}$ & $\begin{array}{l}\text { Грудний збір № } 1 \\
\text { збір, фрільтр-пакети }\end{array}$ & ПрАТ «Ліктрави», Україна \\
\hline \multirow[t]{5}{*}{$\begin{array}{l}\text { N05 психолептичні засоби, } \\
\text { Снодійна та седативна }\end{array}$} & $\begin{array}{l}\text { Пасифрлори трава } \\
\text { Липи квітки } \\
\text { Материнки трава } \\
\text { Шавлії листя } \\
\text { Меліси трава }\end{array}$ & $\begin{array}{l}\text { Беліса, } \\
\text { краплі оральні }\end{array}$ & $\begin{array}{l}\text { ТОВ «ДКП } \\
\text { «Фармацевтична } \\
\text { фрабрика», Україна }\end{array}$ \\
\hline & $\begin{array}{l}\text { Пасифрлори трава } \\
\text { Липи квітки } \\
\text { Материнки трава } \\
\text { Шавлії листя } \\
\text { Меліси трави }\end{array}$ & $\begin{array}{l}\text { Беліса, } \\
\text { капсули }\end{array}$ & $\begin{array}{l}\text { ТОВ «ДКП } \\
\text { «Фармацевтична } \\
\text { фрабрика», Україна }\end{array}$ \\
\hline & $\begin{array}{l}\text { Пустирника трава } \\
\text { Материнки трава } \\
\text { Чебрецю трава } \\
\text { Валеріани кореневища } 3 \\
\text { коренями } \\
\text { Буркуну трава } \\
\end{array}$ & $\begin{array}{l}\text { Фітоседан, збір фрільтр- } \\
\text { пакети }\end{array}$ & ПрАТ «Ліктрави», Україна \\
\hline & $\begin{array}{l}\text { Глоду плоди } \\
\text { Хмелю шишки } \\
\text { Собача кропива трава } \\
\text { Кропиви листя } \\
\text { Шавлії листя } \\
\text { Материнки трава } \\
\text { Беладонни листя } \\
\end{array}$ & $\begin{array}{l}\text { Скріпта, } \\
\text { настойка }\end{array}$ & $\begin{array}{l}\text { ПАТ «Хімфрармзавод } \\
\text { «Червона зірка», Україна }\end{array}$ \\
\hline & $\begin{array}{l}\text { Глоду плоди } \\
\text { Хмелю шишки } \\
\text { Пустирника трава } \\
\text { Кропиви листя } \\
\text { Шавлії листя } \\
\text { Материнки трава } \\
\text { Беладонни листя }\end{array}$ & $\begin{array}{l}\text { Клімапін® } \\
\text { настойка }\end{array}$ & $\begin{array}{l}\text { ПАТ «Хімфрармзавод } \\
\text { «Червона зірка», Україна }\end{array}$ \\
\hline $\begin{array}{l}\text { G04 засоби, що } \\
\text { застосовуються в урології } \\
\text { Інші засоби, що } \\
\text { застосовуються в урології, } \\
\text { Комбінований засіб }\end{array}$ & $\begin{array}{l}\text { Ялиці олія } \\
\text { Олії м'яти перцевої } \\
\text { Моркви дикої плодів } \\
\text { екстракт рідкий } \\
\text { Хмелю шишок екстракт рідкий } \\
\text { Материнки трави екстракт } \\
\text { рідкий }\end{array}$ & $\begin{array}{l}\text { Уролесан® } \\
\text { капсули }\end{array}$ & $\begin{array}{l}\text { ПАТ «Київмедпрепарат», } \\
\text { Україна }\end{array}$ \\
\hline
\end{tabular}

ISSN 2312-0967. Фармацевтичний часопис. 2021. № 3 
Фармацевтичний менеджмент, маркетинг та логістика Pharmaceutical management, marketing and logistics

Продовження табл. 1

\begin{tabular}{|c|c|c|c|}
\hline \multirow[t]{3}{*}{1} & 2 & 3 & 4 \\
\hline & $\begin{array}{l}\text { Ялиці олія } \\
\text { Олії м'яти перцевої } \\
\text { Моркви дикої плодів } \\
\text { екстракт рідкий } \\
\text { Хмелю шишок екстракт рідкий } \\
\text { Материнки трави екстракт } \\
\text { рідкий }\end{array}$ & Уролесан®, сироп & $\begin{array}{l}\text { ПАТ «Галичфрарм», } \\
\text { Україна }\end{array}$ \\
\hline & $\begin{array}{l}\text { Ялиці олія } \\
\text { Олії м'яти перцевої } \\
\text { Моркви дикої плодів } \\
\text { екстракт рідкий } \\
\text { Хмелю шишок екстракт рідкий } \\
\text { Материнки трави екстракт } \\
\text { рідкий }\end{array}$ & $\begin{array}{l}\text { Уролесан® } \\
\text { краплі оральні }\end{array}$ & $\begin{array}{l}\text { ПАТ «Галичфрарм», } \\
\text { Україна }\end{array}$ \\
\hline $\begin{array}{l}\text { G02 інші гінекологічні } \\
\text { засоби, } \\
\text { Інші засоби, що } \\
\text { застосовуються в } \\
\text { гінекології }\end{array}$ & $\begin{array}{l}\text { Грициків звичайних трава } \\
\text { Деревію трава } \\
\text { Нагідок квітки } \\
\text { Ромашки квітки } \\
\text { Аїру корені } \\
\text { Материнки трава } \\
\text { Барвінку трава } \\
\text { Звіробою трава } \\
\text { Чистотілу трава }\end{array}$ & $\begin{array}{l}\text { Гінекофріт } \\
\text { настойка }\end{array}$ & $\begin{array}{l}\text { ТОВ «Науково-виробнича } \\
\text { фрармацевтична компанія } \\
\text { «Ейм», Україна }\end{array}$ \\
\hline
\end{tabular}

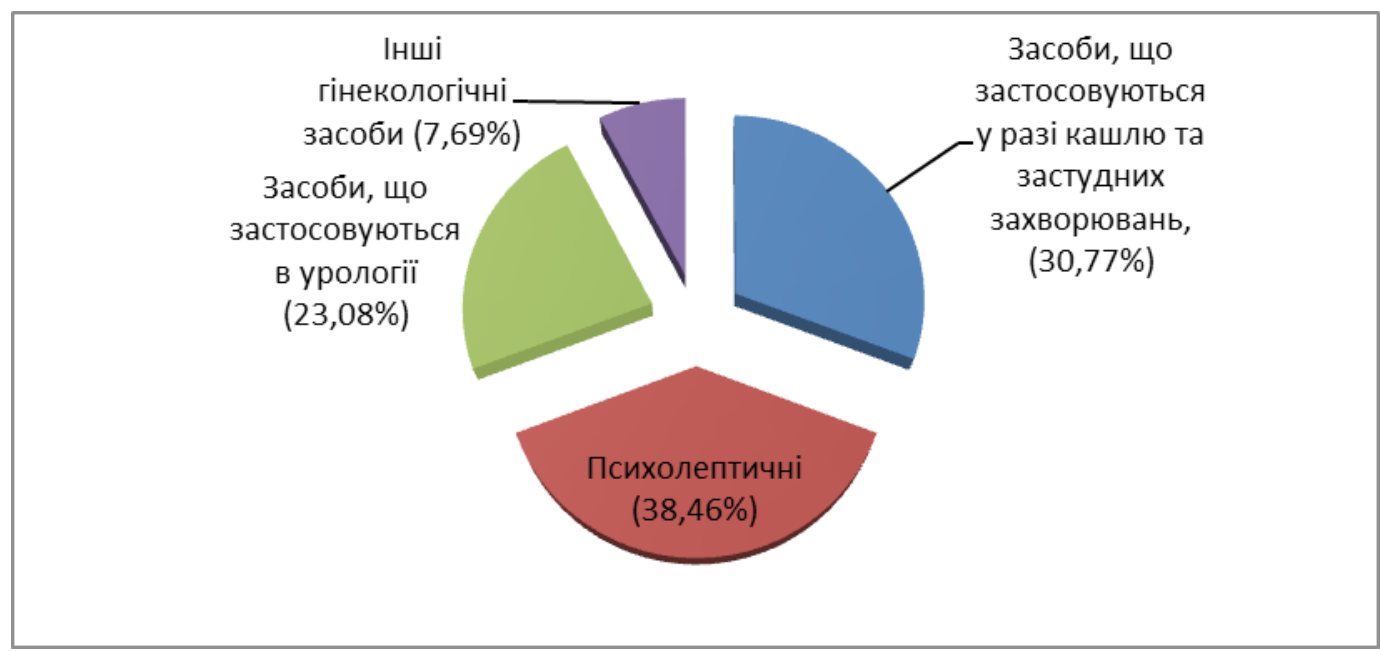

Рис. 3. Розподіл асортименту препаратів із вмістом материнки звичайної згідно з класифікацією АТС.

Оскільки пеларгонія очиткова входить до складу 9 препаратів зареєстрованих на ринку України і 2 препаратів фрармацевтичного ринку Польщі, здійснено їх аналіз щодо належності до відповідної фрармакологічної групи згідно з АТС-класифрікацією (табл. 3).

Залежно від кількості рослинних компонентів у фрітозасобі їх поділяють на однокомпонентні та багатокомпонентні. Згідно 3 даними Державного реєстру лікарських засобів України [8] і Реєстру препаратів лікувальних Польщі [7], більшу частину асортименту складають однокомпонентні препарати 73,33 \% та 91,7 \% відповідно (рис. 4). Тому поєднання цих трьох рослин в одній лікарській формі $є$ перспективним, оскільки аналогів цьому ще немає.

Аналіз асортименту препаратів українського фрармацевтичного ринку дав змогу зробити висновок, що більшість препаратів трави материнки, листя плюща і коренів пеларгонії вироблені на

ISSN 2312-0967. Pharmaceutical review. 2021. № 3 
Фармацевтичний менеджмент, маркетинг та логістика Pharmaceutical management, marketing and logistics

\section{Таблиця 2}

Розподіл наявних на фрармацевтичному ринку України та Польщі препаратів листя плюща залежно від класифікації АТC

\begin{tabular}{|c|c|c|c|}
\hline $\begin{array}{l}\text { Назва групи згідно із } \\
\text { АТС-класифрікацією, } \\
\text { фрармакологічна дія }\end{array}$ & Рослинні компоненти & Препарати & Виробник \\
\hline 1 & 2 & 3 & 4 \\
\hline \multicolumn{4}{|c|}{ Україна } \\
\hline \multirow{5}{*}{$\begin{array}{l}\text { R05 засоби, що } \\
\text { застосовуються у разі } \\
\text { кашлю та застудних } \\
\text { захворювань, } \\
\text { Віхаркувальна }\end{array}$} & Листя плюща & $\begin{array}{l}\text { Сироп від кашлю } \\
\text { др. Тайсса з екстрактом } \\
\text { плюща, } \\
\text { сироп }\end{array}$ & $\begin{array}{l}\text { Др. Тайсс Натурварен ГмбХ, } \\
\text { Німеччина }\end{array}$ \\
\hline & Листя плюща & Гербіон® сироп сироп & $\begin{array}{l}\text { КРКА, д.Д., Ново место, } \\
\text { Словенія }\end{array}$ \\
\hline & Листя плюща & $\begin{array}{l}\text { Хедерал® плющ } \\
\text { сироп }\end{array}$ & АТ «ВІТАМІНИ», Україна \\
\hline & Листя плюща & $\begin{array}{l}\text { Гербіон® плющ } \\
\text { льодяники }\end{array}$ & $\begin{array}{l}\text { КРКА, Д.Д., Ново место, } \\
\text { Словенія }\end{array}$ \\
\hline & Листя плюща & $\begin{array}{l}\text { Гербалор плющ проти } \\
\text { кашлю } \\
\text { сироп }\end{array}$ & $\begin{array}{l}\text { МЕДАНА ФАРМА Акціонерне } \\
\text { Товариство, Польща/ } \\
\text { Фармацевтичний завод } \\
\text { «ПОЛЬФАРМА» С.А., Польща }\end{array}$ \\
\hline \multirow{9}{*}{$\begin{array}{l}\text { R05 засоби, що } \\
\text { застосовуються у разі } \\
\text { кашлю та застудних } \\
\text { захворювань }\end{array}$} & Листя плюща & $\begin{array}{l}\text { Пектолван® Плющ } \\
\text { сироп }\end{array}$ & АТ «Фармак», Україна \\
\hline & Листя плюща & $\begin{array}{l}\text { Пектолван® Плющ } \\
\text { капсули }\end{array}$ & АТ «Фармак», Україна \\
\hline & Листя плюща & $\begin{array}{l}\text { Гриппостад® Гербал } \\
\text { сироп }\end{array}$ & $\begin{array}{l}\text { СТАДА Арцнайміттель АГ, } \\
\text { Німеччина }\end{array}$ \\
\hline & Листя плюща & $\begin{array}{l}\text { Плюща сироп } \\
\text { сироп }\end{array}$ & $\begin{array}{l}\text { ПрАТ Фармацевтична срабрика } \\
\text { «Віола», Україна }\end{array}$ \\
\hline & Листя плюща & $\begin{array}{l}\text { Геделикс® Краплі без } \\
\text { спирту } \\
\text { краплі оральні }\end{array}$ & $\begin{array}{l}\text { Кревель Мойзельбах ГмбХ, } \\
\text { Німеччина }\end{array}$ \\
\hline & Листя плюща & $\begin{array}{l}\text { Бронхолекс } \\
\text { розчин оральний }\end{array}$ & $\begin{array}{l}\text { Салютас Фарма ГмбХ, } \\
\text { Німеччина } \\
\text { Фарма Вернігероде ГмбХ, } \\
\text { Німеччина } \\
\text { Фітолаб ГмбХ \& Ко.КГ, } \\
\text { Німеччина/Сандоз } \\
\text { Фармасьютікалз д.Д., Словенія }\end{array}$ \\
\hline & Листя плюща & $\begin{array}{l}\text { Геделикс® Сироп від } \\
\text { кашлю } \\
\text { сироп }\end{array}$ & $\begin{array}{l}\text { Кревель Мойзельбах ГмбХ, } \\
\text { Німеччина }\end{array}$ \\
\hline & $\begin{array}{l}\text { Трави чебрецю } \\
\text { Листя плюща }\end{array}$ & $\begin{array}{l}\text { Бронхипрет® } \\
\text { сироп }\end{array}$ & Біонорика СЕ, Німеччина \\
\hline & Листя плюща & $\begin{array}{l}\text { Хедуссін } \\
\text { сироп }\end{array}$ & Фітофрарм Кленка С.А., Польща \\
\hline \multirow{2}{*}{$\begin{array}{l}\text { R05 засоби, що } \\
\text { застосовуються у разі } \\
\text { кашлю та застудних } \\
\text { захворювань }\end{array}$} & Листя плюща & $\begin{array}{l}\text { Гедерин } \\
\text { сироп }\end{array}$ & $\begin{array}{l}\text { ТОВ «ДКП «Фармацевтична } \\
\text { фрабрика», Україна }\end{array}$ \\
\hline & Листя плюща & $\begin{array}{l}\text { Гедерин } \\
\text { капсули блістера в коробці }\end{array}$ & $\begin{array}{l}\text { ТОВ «ДКП «Фармацевтична } \\
\text { фабрика», Україна }\end{array}$ \\
\hline
\end{tabular}

ISSN 2312-0967. Фармацевтичний часопис. 2021. № 3 
Фармацевтичний менеджмент, маркетинг та логістика Pharmaceutical management, marketing and logistics

Продовження табл. 2

\begin{tabular}{|c|c|c|c|}
\hline 1 & 2 & 3 & 4 \\
\hline & Листя плюща & $\begin{array}{l}\text { Рітоссе } ® \text { плющ } \\
\text { сироп }\end{array}$ & $\begin{array}{l}\text { ПрАТ «Фармацевтична фрірма } \\
\text { «Дарниця», Україна }\end{array}$ \\
\hline & Листя плюща & $\begin{array}{l}\text { Проспан® Форте таблетки } \\
\text { шипучі від кашлю } \\
\text { таблетки шипучі }\end{array}$ & $\begin{array}{l}\text { Енгельгард Арцнайміттель } \\
\text { ГмбХ \& Ко. КГ , Німеччина } \\
\text { Гермес Арцнайміттель ГмбХ, } \\
\text { Німеччина/ } \\
\text { Енгельгард Арцнайміттель } \\
\text { ГмбХ \& Ко. КГ, Німеччина }\end{array}$ \\
\hline & Листя плюща & $\begin{array}{l}\text { Бронхипрет® } \\
\text { розчин }\end{array}$ & Біонорика СЕ, Німеччина \\
\hline & Листя плюща & $\begin{array}{l}\text { Проспан® розчин від } \\
\text { кашлю } \\
\text { розчин оральний }\end{array}$ & $\begin{array}{l}\text { Енгельгард Арцнайміттель } \\
\text { ГмбХ \& Ко. КГ, Німеччина }\end{array}$ \\
\hline & Листя плюща & $\begin{array}{l}\text { Проспан® пастилки } \\
\text { для розсмоктування від } \\
\text { кашлю } \\
\text { пастилки для } \\
\text { розсмоктування }\end{array}$ & $\begin{array}{l}\text { Енгельгард Арцнайміттель } \\
\text { ГмбХ \& Ко. КГ, Німеччина } \\
\text { Болдер Арцнайміттель ГмбХ і } \\
\text { Ко. КГ, Німеччина }\end{array}$ \\
\hline & Листя плюща & $\begin{array}{l}\text { Проспан® краплі від } \\
\text { кашлю } \\
\text { краплі }\end{array}$ & $\begin{array}{l}\text { Енгельгард Арцнайміттель } \\
\text { ГмбХ \& Ко. КГ, Німеччина }\end{array}$ \\
\hline $\begin{array}{l}\text { R05 засоби, що } \\
\text { застосовуються у разі } \\
\text { кашлю та застудних } \\
\text { захворювань }\end{array}$ & Листя плюща & $\begin{array}{l}\text { Проспан® сироп від } \\
\text { кашлю } \\
\text { сироп }\end{array}$ & $\begin{array}{l}\text { Енгельгард Арцнайміттель } \\
\text { ГмбХ \& Ко.КГ, Німеччина } \\
\text { Мерц Фарма ГмбХ і Ко. КГаА, } \\
\text { Німеччина } \\
\text { Ліхтенхельдт ГмбХ, } \\
\text { Фармацевтична орабрика, } \\
\text { Німеччина }\end{array}$ \\
\hline V03 інші засоби & $\begin{array}{l}\text { Арніка гірська } \\
\text { Ломиніс прямий } \\
\text { Болиголов плямистий } \\
\text { Ранник вузлуватий } \\
\text { Гіркокаштан звичайний } \\
\text { Плющ звичайний }\end{array}$ & $\begin{array}{l}\text { Ітірес Зал Спаг. Пєка } \\
\text { мазь }\end{array}$ & $\begin{array}{l}\text { Пекана Натурхайльміттель } \\
\text { ГмбХ, Німеччина }\end{array}$ \\
\hline \multicolumn{4}{|c|}{ Польща } \\
\hline \multirow{6}{*}{$\begin{array}{l}\text { R05 засоби, що } \\
\text { застосовуються у разі } \\
\text { кашлю та застудних } \\
\text { захворювань }\end{array}$} & $\begin{array}{l}\text { Трави чебрецю } \\
\text { Листя плюща }\end{array}$ & $\begin{array}{l}\text { Bronchipret, syrop } \\
\text { (Бронхіпрет, сироп) }\end{array}$ & $\begin{array}{l}\text { Bionorica SE, } \\
\text { Німеччина }\end{array}$ \\
\hline & Листя плюща & $\begin{array}{l}\text { Hedecton, syrop } \\
\text { (Гедектон, сироп) }\end{array}$ & $\begin{array}{l}\text { Krewel Meuselbach GmbH, } \\
\text { Німеччина }\end{array}$ \\
\hline & Листя плюща & $\begin{array}{l}\text { Hedelix, syrop } \\
\text { (Геделікс, сироп) }\end{array}$ & $\begin{array}{l}\text { Fortis Pharmaceuticals Sp, } \\
\text { Польща }\end{array}$ \\
\hline & Листя плюща & $\begin{array}{l}\text { Hedelix, Tabletka musująca } \\
\text { (Геделікс, таблетка } \\
\text { шипуча) }\end{array}$ & $\begin{array}{l}\text { Krewel Meuselbach GmbH, } \\
\text { Німеччина }\end{array}$ \\
\hline & Листя плюща & $\begin{array}{l}\text { Hedera Helix Sanofi, syrop } \\
\text { (Гедера Гелікс Санофрi, } \\
\text { сироп) }\end{array}$ & $\begin{array}{l}\text { Sanofi-Aventis Sp. z o.o., } \\
\text { Польща }\end{array}$ \\
\hline & Листя плюща & $\begin{array}{l}\text { Hederasal, syrop } \\
\text { (Гедерасал, сироп) }\end{array}$ & $\begin{array}{l}\text { Wrocławskie Zakłady Zielarskie } \\
\text { «Herbapol» S.A., Польща }\end{array}$ \\
\hline
\end{tabular}

ISSN 2312-0967. Pharmaceutical review. 2021. № 3 
Фармацевтичний менеджмент, маркетинг та логістика Pharmaceutical management, marketing and logistics

Продовження табл. 2

\begin{tabular}{|c|c|c|c|}
\hline 1 & 2 & 3 & 4 \\
\hline & Листя плюща & $\begin{array}{l}\text { Hederoin, Tabletki } \\
\text { (Гедероін, таблетки) }\end{array}$ & $\begin{array}{l}\text { Wrocławskie Zakłady Zielarskie } \\
\text { «Herbapol» S.A., Польща }\end{array}$ \\
\hline & Листя плюща & $\begin{array}{l}\text { Hedussin, syrop } \\
\text { (Гедуссін, сироп) }\end{array}$ & Phytopharm Klęka S.A. , Польща \\
\hline & Листя плюща & $\begin{array}{l}\text { HeliPico, syrop } \\
\text { (ГеліПіко, сироп) }\end{array}$ & Medana Pharma S.A., Польща \\
\hline & Листя плюща & $\begin{array}{l}\text { Helituspan, syrop } \\
\text { (Гелітуспан, сироп) }\end{array}$ & Sopharma AD, Болгарія \\
\hline & Листя плюща & $\begin{array}{l}\text { Herbion na kaszel mokry, } \\
\text { pastylki twarde } \\
\text { (Гербіон від вологого } \\
\text { кашлю, пастилки тверді) }\end{array}$ & Krka, d.d., Novo mesto, Словенія \\
\hline & Листя плюща & $\begin{array}{l}\text { Herbion na kaszel mokry, } \\
\text { syrop } \\
\text { (Гербіон від вологого } \\
\text { кашлю, сироп) }\end{array}$ & $\begin{array}{l}\text { Krka, d.d., Novo mesto, } \\
\text { Словенія }\end{array}$ \\
\hline & Листя плюща & $\begin{array}{l}\text { Herdripsan, syrop } \\
\text { (Гердіпсан, сироп) }\end{array}$ & Dr. Max Pharma s.r.o., Чехія \\
\hline & Листя плюща & $\begin{array}{l}\text { Mituret, syrop } \\
\text { (Мітурет, сироп) }\end{array}$ & Conforma NV, Бельгія \\
\hline & Листя плюща & $\begin{array}{l}\text { Mucohelix, syrop } \\
\text { (Мукогелікс, сироп) }\end{array}$ & Sanofi-Aventis Sp. z о.о, Польща \\
\hline & Листя плюща & $\begin{array}{l}\text { Mucoplant na kaszel } \\
\text { bluszcz, syrop } \\
\text { (Мукоплант плющ, від } \\
\text { кашлю, сироп) }\end{array}$ & $\begin{array}{l}\text { Dr Theiss Naturwaren } \mathrm{GmbH} \text {, } \\
\text { Німеччина }\end{array}$ \\
\hline & Листя плюща & $\begin{array}{l}\text { Pectolvan, syrop } \\
\text { (Пектолван, сироп) }\end{array}$ & $\begin{array}{l}\text { Farmak International Sp. z o.o, } \\
\text { Україна }\end{array}$ \\
\hline & $\begin{array}{l}\text { Листя плюща } \\
\text { Корені солодки } \\
\text { Трава чебрецю }\end{array}$ & $\begin{array}{l}\text { PiniHelix, syrop } \\
\text { (ПініГелікс, сироп) }\end{array}$ & Farmina Sp. z o.o, Польща \\
\hline & Листя плюща & $\begin{array}{l}\text { Prospan, krople doustne, } \\
\text { roztwór } \\
\text { (Проспан, пероральні } \\
\text { краплі, розчин ) }\end{array}$ & $\begin{array}{l}\text { Engelhard Arzneimittel GmbH \& } \\
\text { Co. KG, } \\
\text { Німеччина }\end{array}$ \\
\hline & Листя плюща & $\begin{array}{l}\text { Prospan, pastylki miękkie } \\
\text { (Проспан, пастилки м'які) }\end{array}$ & $\begin{array}{l}\text { Engelhard Arzneimittel GmbH \& } \\
\text { Co. KG, Німеччина }\end{array}$ \\
\hline & Листя плюща & $\begin{array}{l}\text { Prospan, syrop } \\
\text { (Проспан, сироп) }\end{array}$ & $\begin{array}{l}\text { Engelhard Arzneimittel GmbH \& } \\
\text { Co. KG, Німеччина }\end{array}$ \\
\hline & Листя плюща & $\begin{array}{l}\text { Syrop z liścia bluszczu } \\
\text { Phytopharm, syrop } \\
\text { (Фітофрарм сироп, сироп із } \\
\text { листя плюща) }\end{array}$ & $\begin{array}{l}\text { McNeil Healthcare Limited, } \\
\text { Ірландія }\end{array}$ \\
\hline
\end{tabular}

ISSN 2312-0967. Фармацевтичний часопис. 2021. № 3 
Фармацевтичний менеджмент, маркетинг та логістика Pharmaceutical management, marketing and logistics

\section{Таблиця 3}

Розподіл наявних на фрармацевтичному ринку України та Польщі препаратів коренів пеларгонії очиткової згідно 3 класифрікацією АТС

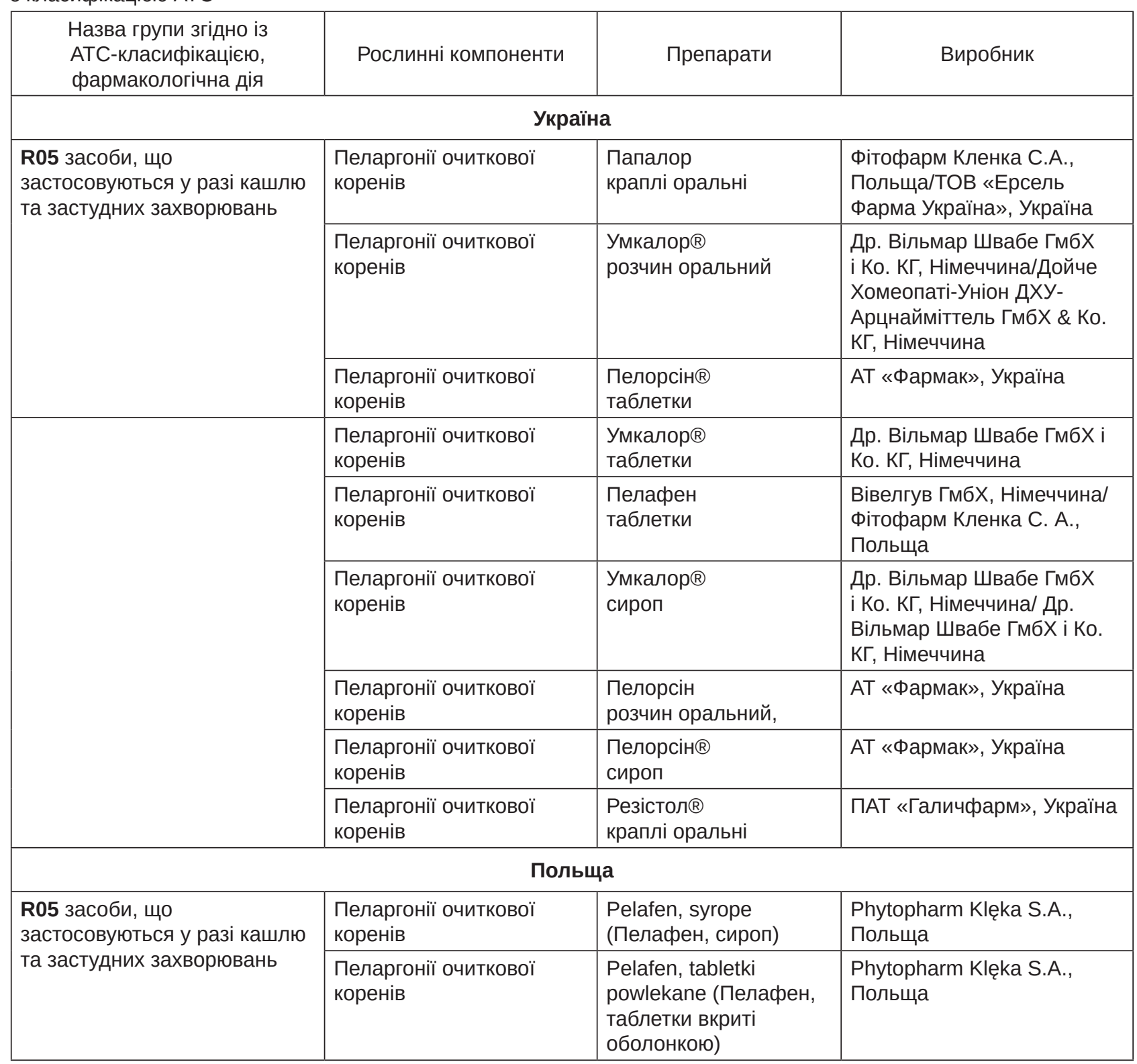

фрармацевтичних підприємствах України (56,14\%), на другому місці Німеччини (29,82 \%). У Польщі найвищий відсоток становлять препарати, виготовленні на польських фармацевтичних підприємствах (40 \%), на другому місці препарати, імпортовані із Німеччини (28 \%) (рис. 5).

Проведені дослідження дали змогу скласти макроконтур цільового сегменту лікарських препаратів із вмістом трави материнки, листя плюща і пеларгонії на національному фрармацевтичному ринку (рис. 6).

Проведені маркетингові дослідження та аналіз асортименту лікарських препаратів із вмістом трави материнки, листя плюща і пеларгонії, які зареєстровані на території України та Польщі, дають змогу зауважити таке:

1) найбільше лікарських засобів зустрічається у вигляді сиропів і крапель в Україні (30,2 \%) та сиропів на ринку Польщі (75\%);

2) більшість з них це однокомпонентні лікарські засоби (73,33 \% - Україна, 91,7 \% - Польща);

3) більшість препаратів представлених на фрармацевтичному ринку України із вмістом трави материнки, листя плюща і коренів пеларгонії, вироблена на фрармацевтичних підприємствах України (56,14 \%), на другому місці розмістилися німецькі

ISSN 2312-0967. Pharmaceutical review. 2021. № 3 
Фармацевтичний менеджмент, маркетинг та логістика Pharmaceutical management, marketing and logistics

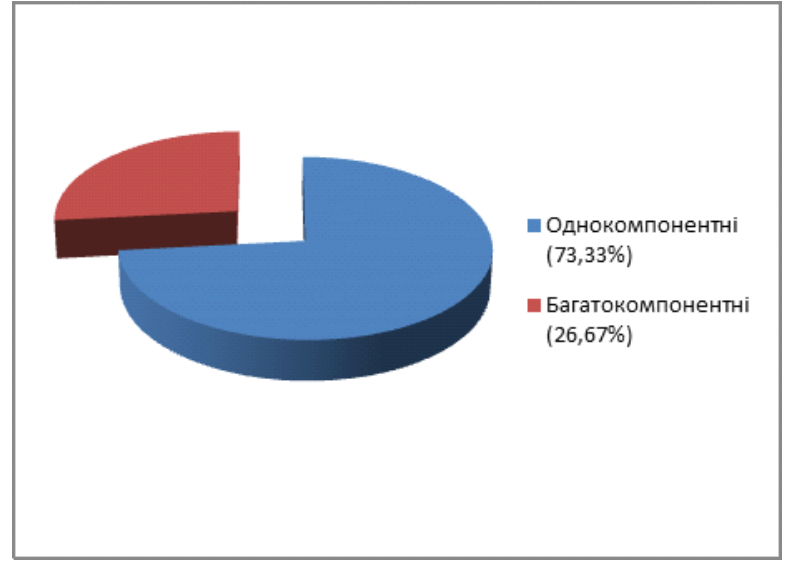

Україна

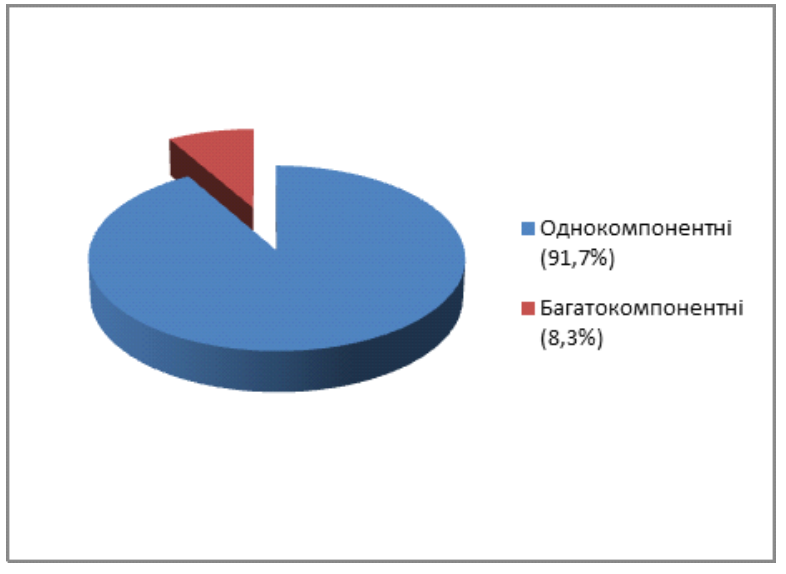

Польща

Рис. 4. Розподіл препаратів за кількісним складом на ринку України та Польщі.

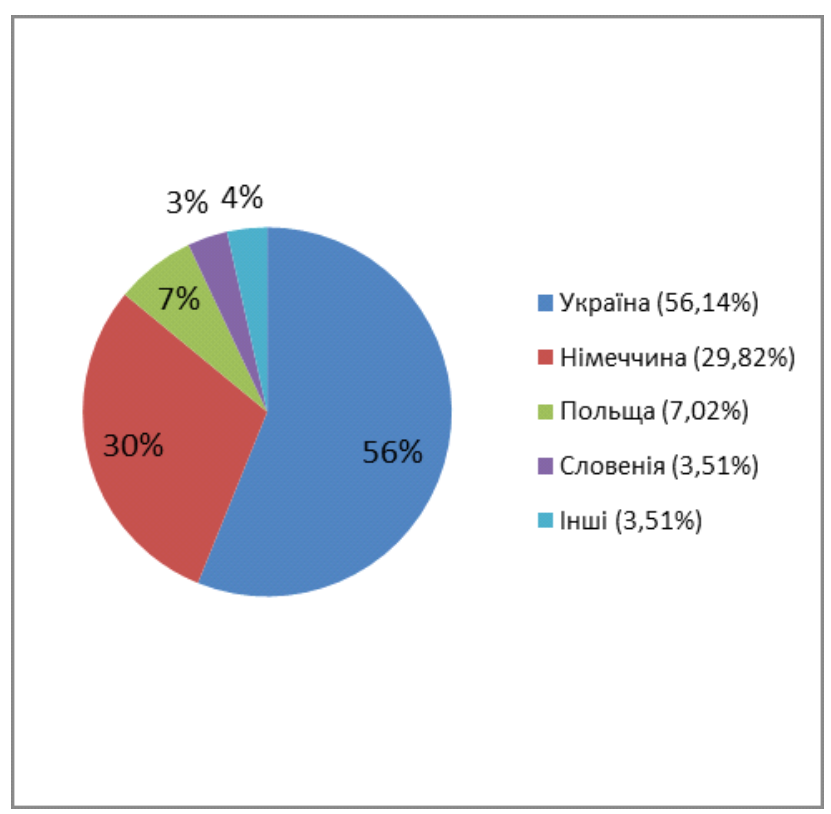

Україна

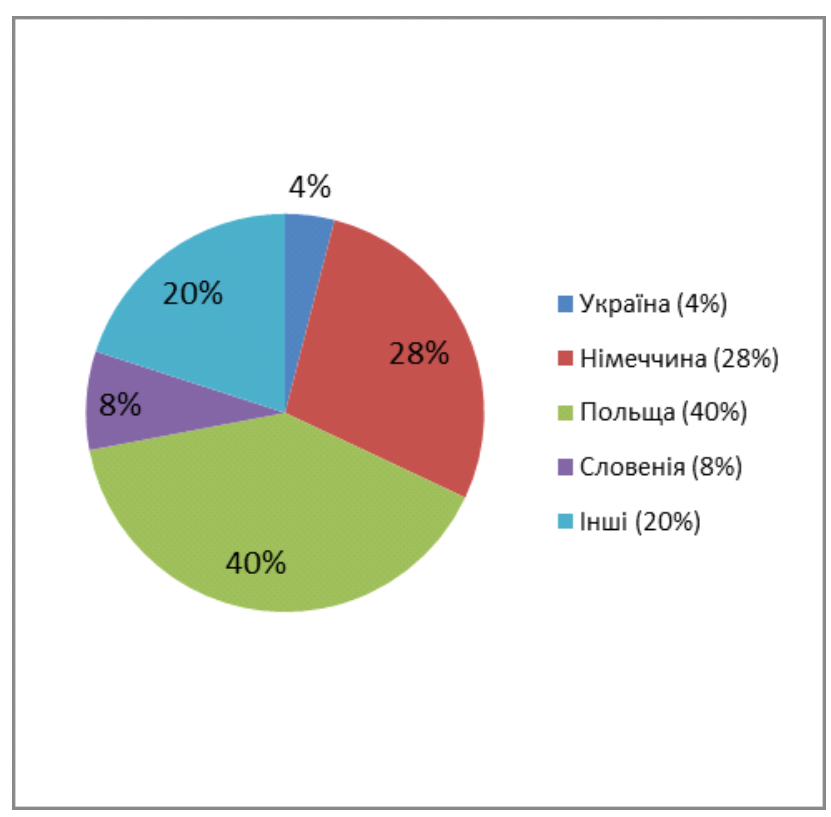

Польща

Рис. 5. Країни-виробники лікарських препаратів із вмістом трави материнки, листя плюща і коренів пеларгонії представлених на ринках України і Польщі.

фрармацевтичні виробники (29,82 \%). В Польщі 3 цієї групи також домінують препарати вітчизняного виробництва (40,0 \%), на другому місці лікарські засоби вироблені на фармацевтичних підприємствах Німеччини (28\%);

4) найчастіше лікарські препарати із вмістом трави материнки, листя плюща і коренів пеларгонії - це за- соби, що застосовуються у разі кашлю та застудних захворювань (78,21 \%);

5) розробка нового багатокомпонентного лікарського засобу із вмістом трави материнки, листя плюща і коренів пеларгонії $€$ перспективною, оскільки аналогів такого препарату на фрармацевтичних ринках України та Польщі немає.

ISSN 2312-0967. Фармацевтичний часопис. 2021. № 3 


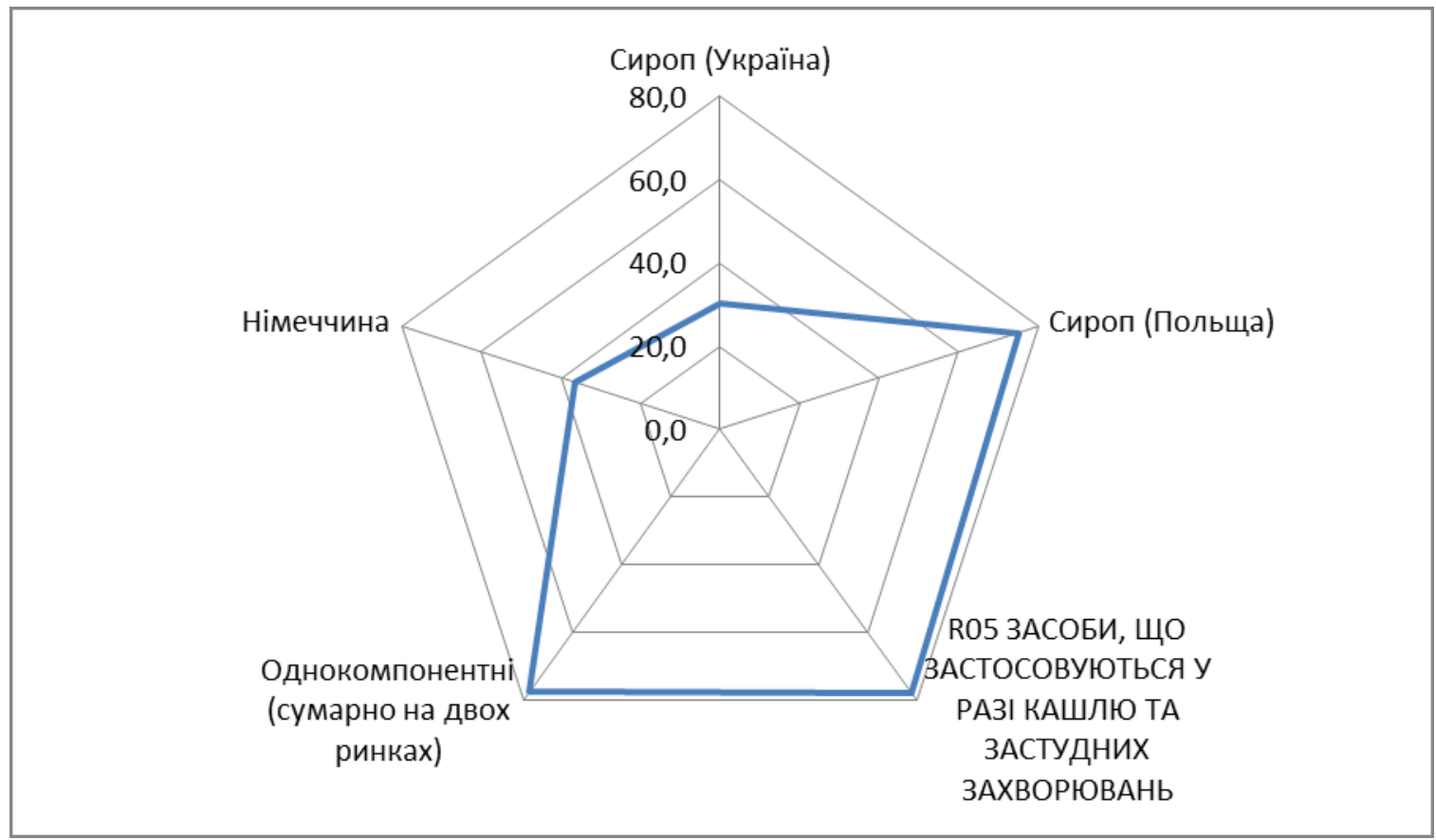

Рис. 6. Макроконтур фрармацевтичного ринку препаратів, до складу яких входять трава материнки, листя плюща і корені пеларгонії.

Висновки. Проведений аналіз українського та польського фрармацевтичних ринків показав, що попри високий асортимент препаратів із вмістом окремих субстанцій Origanum vulgare, Hedera hibernica, Pelargonium Sidoides відсутній препарат, що включав би всі ці рослини разом або комбінації двох із них. Розробка складу та тех- нології нового препарату для лікування захворювань органів дихальної системи з вмістом цих рослин у формі сиропу або пастилок є перспективною на даний час.

Конфрлікт інтересів: відсутній.

Conflicts of interest: authors have no conflict of interest to declare.

\section{PELARGONIUM SIDOIDES, HEDERA HIBERNICA AND ORIGANUM VULGARE IN THE PHARMACEUTICAL PREPARATIONS PRESENTED ON THE MARKETS OF UKRAINE AND POLAND}

\section{O. R. Bryda, N. Ye. Stadnytska}

Lviv Polytechnic National University

brydaoleksandr@gmail.com, nataliia.y.stadnytska@lpnu.ua

The aim of the work. Analyze the range of drugs from the pharmaceutical markets of Ukraine and Poland, which contain substances of pelargonium root (Pelargonium Sidoides), oregano (Origanum vulgare) and ivy leaves (Hedera Hibernica). Based on the obtained results to determine the feasibility of developing a new multicomponent drug with their content.

Materials and Methods. The analysis of pharmaceutical markets was performed according to the data of the State Register of Medicinal Products of Ukraine and Poland (as of July 2021). The work is performed using logical systematizing, generalizing and graphical methods.

Results and Discussion. Most of the analyzed products of the pharmaceutical markets of Ukraine and Poland with the content of pelargonium stonecrop, oregano, ivy are presented in the form of syrups. These are mainly single-component medicines (73.33\% in Ukraine and $91.7 \%$ in Poland). In both countries, the largest percentage of the studied drugs are produced by domestic pharmaceutical companies, in second place drugs are imported from Germany. The most common drugs containing Origanum vulgare, Hedera Hibernica, Pelargonium Sidoides are drugs used for coughs and colds $(78.21 \%)$.

Conclusions. The development of a new multicomponent drug containing oregano, ivy leaves and pelargonium is promising because there are no analogues of such a drug in the domestic pharmaceutical market. 
Фармацевтичний менеджмент, маркетинг та логістика

Pharmaceutical management, marketing and logistics

Key words: pelargonium roots Pelargonium Sidoides; oregano herba Origani vulgare; ivy leaves; Hedera hibernica; herbal preparations; pharmaceutical market of Ukraine; pharmaceutical market of Poland.

\section{Список бібліографрічних посилань}

1. Захворюваність на грип та ГРВІ в Україні. Центр громадського здоров'я України : веб сайт. URL: https://phc.org.ua/kontrol-zakhvoryuvan/inshi-infekciyni-zakhvoryuvannya/monitoring-i-ocinka/zakhvoryuvanist-na-grip-ta-grvi-v-ukraini (дата звернення: липень 2021).

2. Гудзенко А. В., Цуркан О. О., Ковальчук Т. В. Вітчизняний ринок багатокомпонентних лікарських засобів рослинного походження: аналіз стану структура та перспективи розвитку. Фармацевтичний журнал. 2012. № 1. C. 8-12. URL: http://nbuv.gov.ua/ UJRN/pharmazh_2012_1_3.

3. Вплив лікарського засобу Резістол® на гуморальний та клітинний імунітет дітей з рекурентними та гострими вірусними респіраторними захворюваннями: результати дослідження / Квашніна Л. В. та ін. Современная педиатрия, 2018. № 8. С. 104-113. doi 10.15574/SP.2018.96.104

4. Дослідження біологічної активності вторинного екстракту зі шроту трави материнки звичайної (Origanum vulgare) / Павлюк I. В. та ін. Український біофрармацевтичний журнал. 2015. № 1. С. 21-24.

5. Yousefian Z., Golkar P., Mirjalili M. H. Production enhancement of medicinally active coumarin and phenolic compounds in hairy root cultures of Pelargonium sidoides: the effect of elicitation and sucrose. Journal of Plant Growth Regulation. 2021. Vol. 40, No. 2. P. 628-641.

6. Widyastuti P. A. Phytochemicals and antioxidant activities evaluation of Origanum vulgare (L.) Stem Bark extracts. Pharmacognosy Journal. 2021. Vol. 13, No. 4. DOI:10.5530/pj.2021.13.124

7. de Torre M. P., Vizmanos J. L., Cavero R. Y., Calvo M. I. Improvement of antioxidant activity of oregano (Origa- num vulgare L.) with an oral pharmaceutical form. Biomedicine \& Pharmacotherapy. 2020. No.129. P.110424.

8. Fazio S. Tolerance, safety and efficacy of Hedera helix extract in inflammatory bronchial diseases under clinical practice conditions: a prospective, open, multicentre postmarketing study in 9657 patients. Phytomedicine. 2009. Vol. 16, No. 1. P.17-24. DOI https://doi. org/10.1016/j.phymed.2006.05.003

9. Zazharskyi V. V. Antibacterial and fungicidal activities of ethanol extracts from Cotinus coggygria, Rhus typhina, R. trilobata, Toxicodendron orientale, Hedera helix, Aralia elata, Leptopus chinensis and Mahonia aquifolium. Regulatory Mechanisms in Biosystems. 2020. Vol. 11, No. 2. P. 305-309. URL: https://doi. org/10.15421/022046

10. Song J. H. Antiviral activity of hederasaponin B from hedera helix against enterovirus 71 subgenotypes C3 and C4a. Biomolecules \& Therapeutics. 2014. No. 22.1(41). P. 108 DOI doi: 10.4062/biomolther.2013.

11. Пошук лікарських засобів. Сайт Державної реєстрації лікарських засобів України : веб сайт. URL: $\quad$ http://www.drlz.com.ua/ibp/ddsite.nsf/all/ shlist?opendocument (дата звернення: липень 2021)

12. Пошук лікарських засобів. Реєстр препаратів лікувальних Польщі : веб сайт. URL: http://pub.rejestrymedyczne.csioz.gov.pl/ (дата звернення: липень 2021)

13. АТС-класисрікація. Компендіум- довідник ліків в Україні : веб сайт. URL: https://compendium.com.ua/ uk/atc/ (дата звернення: липень 2021)

14. Про лікарські засоби : Закон України від 17.05.2007 № 1034-V (1034-16). URL: https://rav.com.ua/useful_ know/norm_baza/zakon/law_medical_products/ (дата звернення: липень 2021).

\section{References}

1. Incidence of influenza and SARS in Ukraine [Internet]. Public Health Center of Ukraine [cited 2021 July 20] Available from: URL: https://phc.org.ua/kontrol-zakhvoryuvan/inshi-infekciyni-zakhvoryuvannya/monitoring-i-ocinka/zakhvoryuvanist-na-grip-ta-grvi-v-ukraini. Ukrainian.

2. Hudzenko AV, Tsurkan OO, Kovalchuk TV. [Domestic market of multicomponent herbal medicines: analysis of the state structure and prospects of development]. Farmatsevtychnyi zhurnal. 2012;1: 8-12. Available from: URL: http://nbuv.gov.ua/UJRN/pharmazh_2012_1_3. Ukrainian.

3. Kvashnina LV, Chernyshov VP, Matviienko IM, Ihnatova TB, Osypchuk DV. [The effect of the drug Resistol ${ }^{\circledR}$ on the humoral and cellular immunity of children with recurrent and acute viral respiratory diseases: the re-

sults of the study]. Sovremennaia pedyatryia. 2018;8: 104-113. Russian.

4. Pavliuk IV, Stadnytska NYe, Yasitska-Misiak I, Vechorek P, Zahorii HV, Brezvyn OM, Novikov VP. [Study of the biological activity of the secondary extract from the meal of oregano (Origanum vulgare)]. Ukrainskyi biofarmatsevtychnyi zhurnal. 2015;1: 21-24. Ukrainian.

5. Yousefian Z, Golkar P, Mirjalili MH. Production Enhancement of medicinally active coumarin and phenolic compounds in hairy root cultures of Pelargonium sidoides: the effect of elicitation and sucrose. Journal of Plant Growth Regulation. 2021;40(2): 628-641.

6. Widyastuti PA. Phytochemicals and antioxidant activities evaluation of Origanum vulgare (L.) Stem Bark Extracts. Pharmacognosy Journal. 2021;13.4. DOI:10.5530/pj.2021.13.124

ISSN 2312-0967. Фармацевтичний часопис. 2021. № 3 
Фармацевтичний менеджмент, маркетинг та логістика Pharmaceutical management, marketing and logistics

7. Torre MP, Vizmanos JL, Cavero RY, Calvo MI. Improvement of antioxidant activity of oregano (Origanum vulgare L.) with an oral pharmaceutical form. Biomedicine \& Pharmacotherapy, 2020;129: 110424.

8. Fazio S. Tolerance, safety and efficacy of Hedera helix extract in inflammatory bronchial diseases under clinical practice conditions: a prospective, open, multicentre postmarketing study in 9657 patients. Phytomedicine. 2009;16.1: 17-24. DOI https://doi.org/10.1016/j. phymed.2006.05.003

9. Zazharskyi VV. Antibacterial and fungicidal activities of ethanol extracts from Cotinus coggygria, Rhus typhina, R. trilobata, Toxicodendron orientale, Hedera helix, Aralia elata, Leptopus chinensis and Mahonia aquifolium. Regulatory Mechanisms in Biosystems. 2020;11.2: 305-9. Available from: https://doi.org/10.15421/022046
10. Song $\mathrm{JH}$. Antiviral activity of hederasaponin B from hedera helix against enterovirus 71 subgenotypes C3 and C4a." Biomolecules \& Therapeutics 2014;22.1(41): 108. DOI: 10.4062/biomolther.2013.

11. Search for medicines [Internet]. Website of the State Registration of Medicines of Ukraine. [cited 2021 July 20] Available from: http://www.drlz.com.ua/ Ukrainian.

12. Search for medicines [Internet]. The site of the register of medical drugs of Poland. Available from: http://pub. rejestrymedyczne.csioz.gov.pl/ Ukrainian.

13. ATC-classification [Internet]. Compendium is a directory of medicines in Ukraine [cited 2021 July 20] Available from: https://compendium.com.ua/uk/atc/ Ukrainian.

14. Law of Ukraine "On Medicinal Products. Available from: https://rav.com.ua/useful_know/norm_baza/zakon/ law_medical_products/ Ukräinian.

\section{Відомості про авторів}

Брида О. Р. - аспірант, кафредра технології біологічно активних сполук, фрармації та біотехнології, Національний університет «Львівська політехніка», Львів, Україна. E-mail: brydaoleksandr@gmail.com, ORCID 0000-0002-49104308.

Стадницька Н. Є. - канд. хім. наук, доцент кафедри технології біологічно активних сполук, фрармації та біотехнології, Національний університет «Львівська політехніка», Львів, Україна. E-mail: nataliia.y.stadnytska@Ipnu.ua, ORCID 0000-0002-7533-9610.

\section{Information about the authors}

Bryda O. R. - PhD-student of the Department of Technology of Biologically Active Substances, Pharmacy and Biotechnology, Lviv Polytechnic National University, Lviv, Ukraine. E-mail: brydaoleksandr@gmail.com, ORCID 0000-0002-4910-4308 Stadnytska N. Ye. - PhD (Chemistry), Associate Professor of the Department of Technology of Biologically Active Substances, Pharmacy and Biotechnology, Lviv Polytechnic National University, Lviv, Ukraine. E-mail: nataliia.y.stadnytska@ Ipnu.ua, ORCID 0000-0002-7533-9610. 